\title{
CIRRHOSIS INDUCES APOPTOSIS IN RENAL TISSUE THROUGH INTRACELLULAR OXIDATIVE STRESS
}

\author{
Keli Cristina Simões da SILVEIRA', 2, Cassiana Macagnan VIAU ${ }^{2,3}$, Josiane Raskopf COLARES ${ }^{4}$, \\ Jenifer SAFFI ${ }^{2,}$, Norma Possa MARRONI ${ }^{4,5}$ and Marilene PORAWSKI', 5
}

\begin{abstract}
Background - Renal failure is a frequent and serious complication in patients with decompensated cirrhosis. Objective We aimed to evaluate the renal oxidative stress, cell damage and impaired cell function in animal model of cirrhosis. Methods - Secondary biliary cirrhosis was induced in rats by ligation of the common bile duct. We measured TBARS, ROS and mitochondrial membrane potential in kidney as markers of oxidative stress, and activities of the antioxidant enzymes. Relative cell viability was determined by trypan blue dye-exclusion assay. Annexin V-PE was used with a vital dye, 7-AAD, to distinguish apoptotic from necrotic cells and comet assay was used for determined DNA integrity in single cells. Results - In bile duct ligation animals there was significant increase in the kidney lipoperoxidation and an increase of the level of intracellular ROS. There was too an increase in the activity of all antioxidant enzymes evaluated in the kidney. The percentage viability was above $90 \%$ in the control group and in bile duct ligation was $64.66 \%$ and the dominant cell death type was apoptosis. DNA damage was observed in the bile duct ligation. There was a decreased in the mitochondrial membrane potential from $71.40 \% \pm 6.35 \%$ to $34.48 \% \pm 11.40 \%$ in bile duct ligation. Conclusion - These results indicate that intracellular increase of ROS cause damage in the DNA and apoptosis getting worse the renal function in cirrhosis.
\end{abstract}

HEADINGS - Liver cirrhosis. Renal insufficiency. Oxidative stress. Flow cytometry. Reactive oxygen species.

\section{INTRODUCTION}

Liver cirrhosis is a chronic progressive disease that represents an irreversible or slowly reversible stage of hepatic dysfunction, characterized by the formation of fibrotic nodules. It occurs as a result of cicatrization and hepatocellular regeneration, which constitute the main responses of the liver tissue to countless inflammatory, toxic, metabolic and congestive insults ${ }^{(19)}$. Characteristic of liver cirrhosis included cell viability and redox ratio decrease, reactive oxygen species formation, lipid peroxidation, DNA fragmentation, and formation of apoptotic bodies, thus providing potential targets for therapy ${ }^{(7)}$.

Renal failure is a frequent and serious complication in patients with decompensated liver cirrhosis. The loss of renal function is associated with increased mortality and a worse prognosis for liver transplantation. Oxidative stress, the prevalence of oxidant factors over antioxidant mechanisms, is markedly elevated in chronic liver disease and has gain attention as a potential important factor in altered hemodynamics and renal dysfunction in cirrhosis. It induces renal vasoconstriction not only by quenching nitric oxide, but also by increasing production of F2-isoprostanes and endothelin ${ }^{(32)}$. Markedly increased levels of both factors in patients with hepatorenal syndrome in conjunction with increased systemic oxidative stress in cirrhosis, raises the possibility of a pathogenetic role of oxidative stress in hepatorenal syndrome ${ }^{(1)}$.

Experimental and clinical data from several studies have suggested that oxidative stress plays a critical role in chronic liver damage and hepatic fibrosis, contributing for the development of complications of the cirrhosis that more aggravate the state of health of the patient ${ }^{(4,19)}$. The human body possesses numerous antioxidant defences and repair mechanisms against oxidative stress. The major endogenous antioxidant systems include superoxide dismutase (SOD), catalase (CAT), glutathione reductase (GR), and glutathione peroxidase (GPx), which are essential for the detoxification of lipid peroxides and act as free radical scavengers ${ }^{(11)}$. Previous studies have demonstrated that the activity of liver antioxidant systems is reduced with disease severity and the antioxidant treatments have been shown to

\footnotetext{
Declared conflict of interest of all authors: none

Laboratório de Fisiologia, Universidade Federal de Ciências da Saúde de Porto Alegre - UFCSPA, Porto Alegre, RS: ${ }^{2}$ Laboratório de Genética Toxicológica, UFCSPA; ${ }^{3}$ Instituto Nacional de Investigação Translacional em Saúde e Ambiente na Região Amazônica - Rio de Janeiro, RJ: ${ }^{4}$ Laboratório de Estresse Oxidativo, Universidade Luterana do Brasil - ULBRA, Canoas, RS; ${ }^{5}$ Centro de Pesquisa do Hospital de Clínicas de Porto Alegre - UFRGS. Brasil.

Correspondence: Prof. Marilene Porawski, Departamento de Ciências Básicas da Saúde. Universidade Federal de Ciências da Saúde de Porto Alegre (UFCSPA). Rua
} Sarmento Leite, 245 - CEP: 90150-170. Porto Alegre, RS, Brasil. E-mail: marilenep@ufcspa.edu.br 
be beneficial in preventing this process by direct antioxidant effects in liver tissue ${ }^{(8,31)}$.

The common bile duct ligation (BDL) in rats has been used to study cirrhosis and its complications being considered a good model to study hepatorenal syndrome. The main advantage of BDL is to allow the study of renal function alterations in a short period of time. In addition, this model mimics clinical conditions characterized by obstructive jaundice, such as biliary atresia and choledocal cysts ${ }^{(17,23)}$. It has been suggested that alterations in antioxidant mechanisms occur with the pathogenesis of cholestatic hepatic damage, resulting in an imbalance of oxidative and antioxidative processes, which stimulates lipoperoxidation and leads to injuries in several systems. The concentration of bile acids increases in rats after bile duct obstruction, which induces lipid peroxidation, and is probably related to the stimulation of phagocytic activity in polymorphonuclear phagocytes and inflammatory cells ${ }^{(31)}$.

In this study, we aimed to evaluate the renal oxidative stress, cell damage and impaired cell function in animal model of cirrhosis.

\section{METHODS}

\section{Animals and experimental design}

Male Wistar rats weighing $220 \mathrm{~g}$ to $300 \mathrm{~g}$ were maintained under temperature controlled conditions with an artificial 12-h light-dark cycle, and were allowed standard chow and water ad libitum. All studies were performed in accordance with the Ethical Committee for Research Involving Animals of UFCSPA. Hepatic fibrosis was induced by BDL. Briefly, the rats were anaesthetized with $2 \%$ xylazine hydrochloride $(50 \mathrm{mg} / \mathrm{kg})$ and ketamine hydrochloride $(100 \mathrm{mg} / \mathrm{kg})$ administered by i.p. injection. Secondary biliary cirrhosis was induced in animals by double ligation and division of the common bile duct. The animals were sacrificed after 28 days of obstruction, a time at which there is complete development of both cholestasis and fibrosis and clear establishment of liver biochemical changes ${ }^{(12)}$. Animals were randomized in two groups: control animals were sham-operated: $\mathrm{C}(\mathrm{n}=6)$ and those that underwent BDL $(n=6)$.

\section{Histological analysis}

Five-micrometer sections of formalin-fixed and paraffin-embedded kidney slices were processed routinely with hematoxylin-eosin (performed by the Laboratory of Pathology at UFCSPA). A single pathologist, blinded to experimental protocol, analyzed all kidney fragments using light microscopy.

\section{Tissue homogenization}

Frozen kidney from each rat was homogenized in ice-cold phosphate buffer $(\mathrm{KCl} 140 \mathrm{mmol} / \mathrm{L}$, phosphate $(20 \mathrm{mmol} / \mathrm{L}$, $\mathrm{pH}$ 7.4) and centrifuged at $100,000 \mathrm{x}$ g for $10 \mathrm{~min}$, the supernatant was used. Protein concentration was measured according to the method of Lowry et al. ${ }^{(14)}$ using serum bovine albumin as standard.

\section{Renal lipoperoxidation and antioxidant enzyme activities}

The amount of aldehydic products generated by lipid peroxidation was quantified by the thiobarbituric acid reaction using $3 \mathrm{mg}$ of protein/sample ${ }^{(18)}$. Spectrophotometric absorbance was determined in the supernatant at $535 \mathrm{~nm}$. Results were referred to as thiobarbituric acid reactive substances (TBARS). Catalase (EC 1.11.1.6) activity was determined by measuring the exponential disappearance of hydrogen peroxide $\left(\mathrm{H}_{2} \mathrm{O}_{2}\right)$ at $240 \mathrm{~nm}$ and was expressed as nmoles/mg de protein ${ }^{(5)}$. The assay of cytosolic glutathione peroxidase (EC 1.11.1.19) was carried out according to Flohe and Guntzler ${ }^{(9)}$ consisting in the measure of nicothinamide adenine dinucleotideo (NADPH) oxidation by glutathione reductase.

Cytosolic superoxide dismutase (SOD; EC 1.15.1.1) was assayed according to Misra and Fridovich ${ }^{(15)}$ at $30^{\circ} \mathrm{C}$. The rate of autooxidation of epinephrine, which is progressively inhibited by increasing amounts of SOD in the homogenate, was monitored spectrophotometrically at $560 \mathrm{~nm}$. The amount of enzyme that inhibits epinephrine autooxidation at $50 \%$ of the maximum inhibition was defined as $1 \mathrm{U}$ of SOD activity.

\section{Trypan blue dye exclusion assay (TBDE)}

Relative cell viability determined by trypan blue dye-exclusion assay (TBDE) was employed as cytotoxic measurements. For each group, $10 \mu \mathrm{L}$ of homogenates of kidney was mixed with $10 \mu \mathrm{L}$ of $0.4 \%$ trypan-blue solution was then added $^{(29)}$. Cytotoxicity (the cellular growth inhibitory rate) was determined from the number of viable cells (no color) in treated samples as a percentage of the PBS control. We used the Countess ${ }^{\circledR}$ Automated Cell Counter (Invitrogen). The test was carried out according to the instructions of the manufacturer.

\section{Assessment of apoptosis by flow cytometric analysis}

Annexin V-PE was used in conjunction with a vital dye, 7-Amino-actinomycin D (7-AAD), to distinguish apoptotic (Annexin V-PE positive, 7-AAD negative) from necrotic (Annexin V-PE positive, 7-AAD positive) cells. After treatment, cells were trypsinized, collected and resuspended in $40 \mu \mathrm{L}$ of binding buffer with $2 \mu \mathrm{L}$ Annexin V-PE. Cells were incubated for $15 \mathrm{~min}$ in the dark at room temperature. After incubation, $160 \mu \mathrm{L}$ of binding buffer and $2 \mu \mathrm{L}$ of 7-AAD were added. The cells were incubated for $5 \mathrm{~min}$ and additional $200 \mu \mathrm{L}$ of binding buffer was added. Before analyzing, cells were filtered through a cell strainer cap that was fitted to a polystyrene round bottom flow cytometric tube. The data were collected and analyzed by a FACS Calibur flow cytometer with use of CellQuest software, in a total of 10,000 events per sample.

\section{Quantification of cleaved caspase-3 by flow cytometric analysis}

Cells were resuspended in $25 \mu \mathrm{L}$ PBS and fixed with $4 \%$ formaldehyde. After permeabilization and blocking $(0.2 \%$ 
Triton X-100 in PBS and 1\% BSA), cells were incubated with anti-caspase-3 antibody (diluted 1:1000) for $1 \mathrm{~h}$ at room temperature, followed by incubation with anti-rabbit FITC secondary antibody (Uniscience) (diluted 1:1000) for $1 \mathrm{~h}$ at room temperature in the dark. A total of 10,000 events were analyzed per sample by FACS Calibur flow cytometer. Fluorescence intensity in arbitrary units was plotted in histograms; the mean fluorescence intensity was calculated using CellQuest software ${ }^{(30)}$.

\section{Alkaline comet assay}

The alkaline comet assay was performed as described by Singh et al. ${ }^{(26)}$. One hundred cells were scored visually according to the tail length and the amount of DNA present in the tail. Electrophoresis was conducted for $25 \mathrm{~min}$ at $25 \mathrm{~V}$ and $300 \mathrm{~mA}(94 \mathrm{~V} / \mathrm{cm})$. After electrophoresis, the slides were neutralised and silver stained ${ }^{(16)}$. Each comet was given an arbitrary value of $0-4$ ( 0 , undamaged; 4 , maximally damaged), as described by Collins et al. ${ }^{(6)}$. Damage score was thus assigned to each sample and can range from 0 (completely undamaged: 100 cells X 0) to 400 (with maximum damage: 100 cells X 4). International guidelines and recommendations for the comet assay consider that visual scoring of comets is a well-validated evaluation method as it is highly correlated with computer-based image analysis ${ }^{(3,6)}$.

\section{Detection of ROS and Mitochondrial Transmembrane Potential $\Delta \Psi \mathrm{m}$}

Detection of oxidative stress was done by staining the cells with $20 \mu \mathrm{M}$ of 2', 7' dichlorodihydrofluorecein deacetate $\left(\mathrm{H}_{2} \mathrm{DCFDA}\right.$, Sigma) for $30 \mathrm{~min}$ at $37^{\circ} \mathrm{C}$. Cells were analyzed using a FACSCalibur ${ }^{\circledR}$ flow cytometer ${ }^{(2)}$. Mitochondrial potential $\Delta \Psi \mathrm{m}$ was assessed by exposure cells to $1 \mu \mathrm{M}$ of membrane-permeable lipophilic cationic fluorochrome rhodamine 123 (Rh-123; Invitrogen/Molecular Probes) for $30 \mathrm{~min}$ at $37^{\circ} \mathrm{C}$ in the dark. Samples were washed in PBS and analyzed by flow cytometry. A total of 10,000 events were measured per sample. Excitation/Emission wavelengths were $488 \mathrm{~nm}$ and 530/30 $\mathrm{nm}$ respectively. Data was collected in $l o g$ scale and analyzed using Cell Quest Pro ${ }^{\circledR}$ software.

\section{Statistical analysis}

Statistical analysis was performed using GraphPad Prism v5 program (Intuitive Software for Science, São Diego, CA, USA). The difference between two groups was analysed by two-tailed Student's $t$-test. A difference with ${ }^{*} P<0.05 ; * * P<0.01 ; * * * P<0.001$ was considered statistically significant.

\section{RESULTS}

\section{Measurement of lipid peroxidation and antioxidant enzyme activity}

In animals with secondary biliary cirrhosis there was significant increase in kidney lipoperoxidation as measured by the TBARS (nmol/mg protein) (control - $\mathrm{CO}=0.38 \pm$ $0.10 ; \mathrm{BDL}=0.98 \pm 0.23)$. There was too a significant increase in the activity of all antioxidant enzymes evaluated in the kidney: catalase (pmol $/ \mathrm{mg}$ protein) $(\mathrm{CO}=1.53 \pm 0.33$; $\mathrm{BDL}$ $=3.43 \pm 0.14)$, glutathione peroxidase $(\mathrm{nmol} / \mathrm{mg}$ protein) $(\mathrm{CO}=5.20 \pm 1.01 ; \mathrm{BDL}=9.85 \pm 2.85)$ and superoxide dismutase (USOD/mg protein) $(\mathrm{CO}=0.90 \pm 0.78 ; \mathrm{BDL}=$ $5.45 \pm 1.85$ ). (Table 1$)$

TABLE 1. Renal lipoperoxidation and antioxidant enzyme activities in kidneys of control and bile duct ligation (BDL) in rats

\begin{tabular}{lcccc}
\hline \multirow{2}{*}{ Samples } & \multicolumn{4}{c}{ Lipoperoxidation/Antioxidant activity } \\
\cline { 2 - 5 } & $\begin{array}{c}\text { TBARS } \\
(\mathrm{nmol} / \mathrm{mg} \\
\text { protein) }\end{array}$ & $\begin{array}{c}\text { CAT } \\
\text { (pmol/ } \\
\text { mg protein) }\end{array}$ & $\begin{array}{c}\text { GPx } \\
\text { (nmol/mg } \\
\text { protein) }\end{array}$ & $\begin{array}{c}\text { SOD } \\
\text { (SOD U/ } \\
\text { mg protein) }\end{array}$ \\
\hline CO (6) & $0.38 \pm 0.10$ & $1.53 \pm 0.33$ & $5.20 \pm 1.01$ & $0.90 \pm 0.78$ \\
BDL (6) & $0.98 \pm 0.23 * *$ & $3.43 \pm 0.14 *$ & $9.85 \pm 2.85 * 5.45 \pm 1.85 * *$ \\
\hline
\end{tabular}

Data were analyzed by two-tailed Student's $t$-test. A difference with $* P<0.05, * * P<0.01$ was considered statistically significant.

Significant difference compared to control group: TBARS ( $P=0.002)$, CAT $(P=0.017)$, GPx $(P=0.05)$, SOD $(P=0.002)$.

CO: control; BDL: bile duct ligation; (n). Results represente the mean \pm S.D; TBARS Thiobarbituric acid reactive substances; CAT: catalase; GPx: gluthatione peroxidase; SOD: superoxide dismutase

\section{Histological analysis}

No alterations in renal histology were observed in bile duct ligated rats when compared to sham-operated animals as shown on Figure 1.

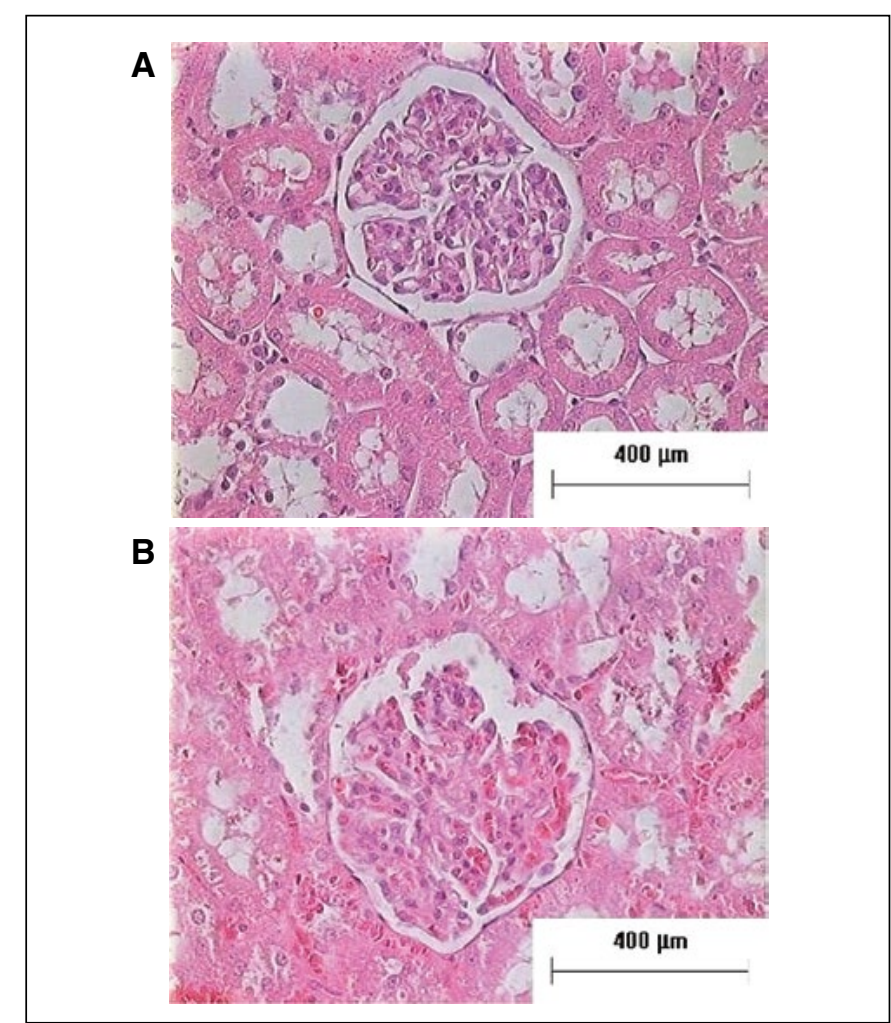

FIGURE 1. Representative micrographs of the renal slices (hematoxylin and eosin) from bile duct ligated (BDL) and sham operated (control) rats. A: control group; B: BDL group. 


\section{Viability and apoptosis analysis}

The results clearly indicated that in control group was virtually nontoxic and had no inhibitory effect on cell proliferation and there was minimal reduction in cell survivability (Figure 2). The percentage viability was above $90 \%$ in the control group $(96.66 \pm 5.57 ; P$ value $=0.0028)$. In addition, in BDL group the percentage viability was $64.66 \pm 14.89$; $P$ value $=0.0028$.

The combination of annexin V-PE/7-AAD provides a convenient way to quantify apoptotic and necrotic cells within the same cell population by flow cytometry. There was an increase in annexin V-PE and 7-AAD staining, in BDL. Approximately $10 \%$ of cells were labeled with annexin-V (early apoptosis), 15\% cells were stained with 7-AAD (late apoptosis), and a great cell population remained unlabeled (with either annexin-V or 7-AAD) $(70 \%)$ compared with the untreated control cells (Figure 3). The percentages of 7-AAD positive cells were less than $6 \%$ for both cells, and the dominant cell death type was apoptosis.

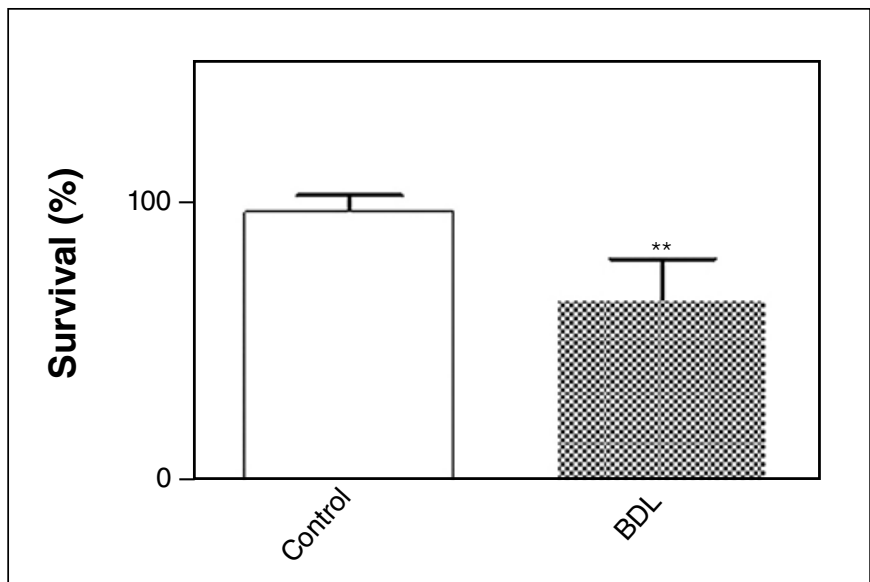

FIGURE 2. Exclusion of trypan blue dye by residual viable control and hepatorenal condition cells was evaluated on Countess ${ }^{\circledR}$ Automated Cell Counter (Invitrogen). Results are expressed as means \pm standard deviation (SD). Data were analyzed by two-tailed Student's $t$-test. A difference with $* * P<0.01$ was considered statistically significant.

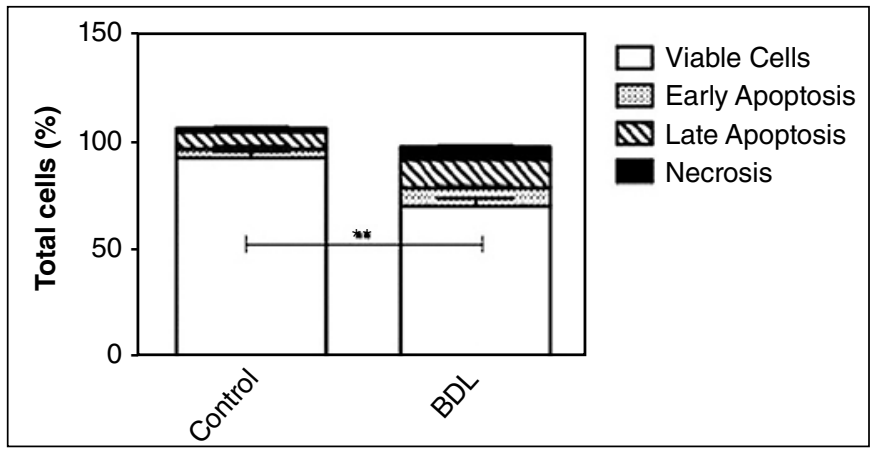

FIGURE 3. There is induction of apoptosis in hepatorenal syndrome. The sum of the percentages of Annexin V and 7-AAD-PE-positive cells was calculated. Results are expressed as means \pm standard deviation (SD). Data were analyzed by two-tailed Student's $t$-test. A difference with $* * P<0.01$ was considered statistically significant.

\section{Quantification of cleaved caspase-3 by flow cytometric analysis}

In order to characterize the apoptosis induced in BDL rats, we evaluated the activation of apoptosis mediators (the cleavage and consequent activation of caspase-3) by flow cytometry using specific antibodies that recognize only the cleaved (active) form of the enzyme. The results, summarized in Figure 4, indicate that in BDL rats leads to increased induction of cleaved caspase-3-labeled cells. These results were consistent with the data from Annexin V-PE positive FACS analysis (Figure 3); in fact, in the BDL rats, we noted a stronger apoptotic effect when compared to control rats (Figures 3-4).

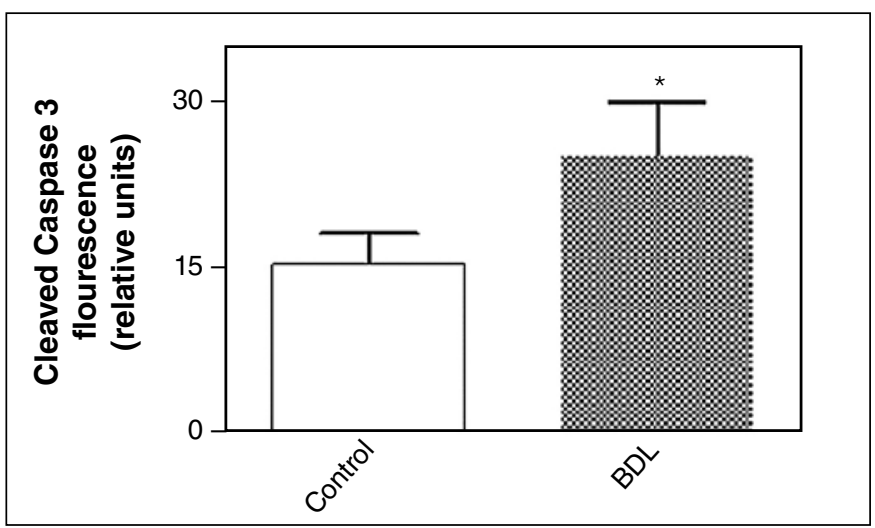

FIGURE 4. There is an induction of cleaved caspase 3 in hepatorenal syndrome. Mean data for cleaved caspase 3 fluorescence. Results are expressed as means \pm standard deviation (SD). Data were analyzed by two-tailed Student's t-test. A difference with $* P<0.05$ was considered statistically significant.

\section{Alkaline comet assay}

We determined DNA integrity in single cells by the comet assay. The control of cells showed no significant increase in genotoxic effects. Significantly elevated DNA damage was observed in the cirrhosis condition (Figure 5).

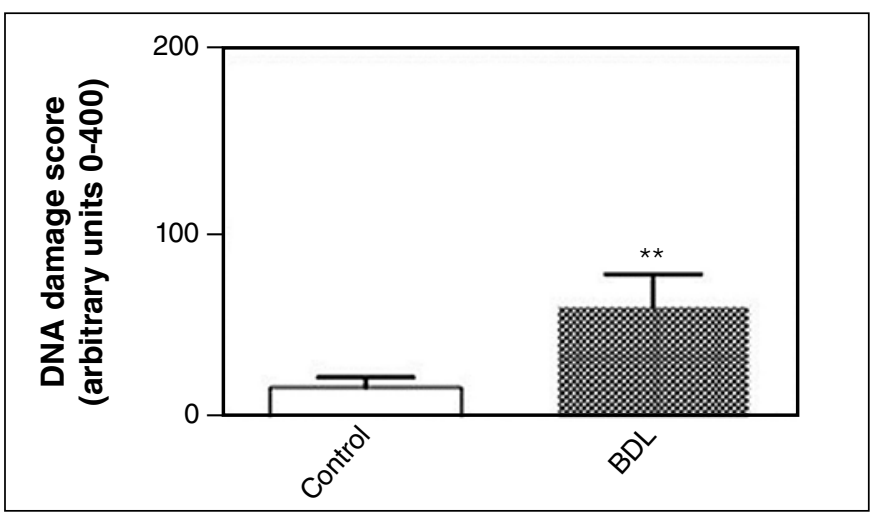

FIGURE 5. Effect of DNA damage index in hepatorenal syndrome, determined by comet assay. Results are expressed as means \pm standard deviation (SD). Data were analyzed by two-tailed Student's t-test. A difference with $* * P<0.01$ was considered statistically significant. 


\section{Intracellular increase of ROS is responsible for apoptosis induced in hepatorenal condition}

Results shown in Figure 6 revealed that in BDL rats there was an increase of the level of intracellular ROS production. These results strongly suggested that apoptosis induced in this condition is likely due to the increase in intracellular ROS

To determine whether the liver injure decreases mitochondrial membrane potential (MMP) in BDL, flow cytometry analysis was carried out using Rhodamine 123 . Compared to control cells, there was a decreased in the MMP from $71.40 \%$ $\pm 6.35 \%$ to $34.48 \% \pm 11.40 \%$ (Figure 7 ).

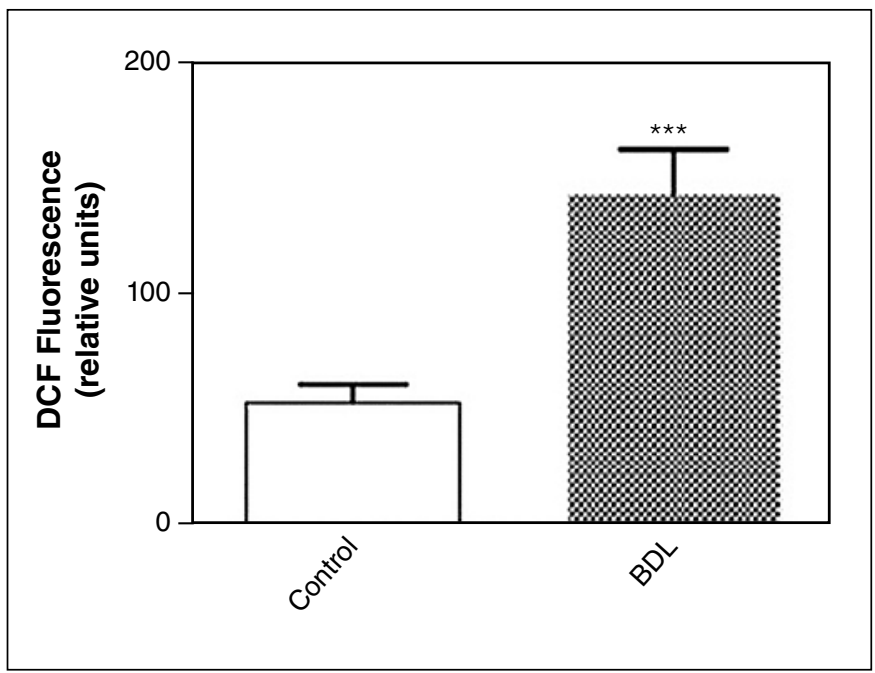

FIGURE 6. Flow cytometry detection of reactive oxygen species in rena homogenates. Mean data for DCF fluorescence. Results are expressed as means \pm standard deviation (SD). Data were analyzed by two-tailed Student's t-test. A difference with $* * * P<0.001$ was considered statistically significant.

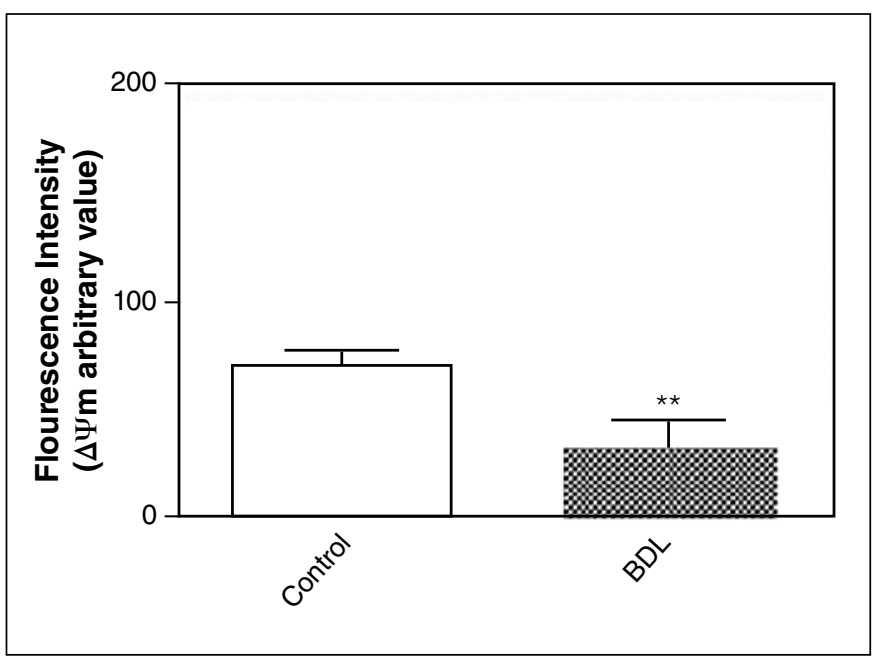

FIGURE 7. There was a reduction on mitochondrial membrane potential in hepatorenal syndrome. Results are expressed as means \pm standard deviation (SD). Data were analyzed by two-tailed Student's t-test. A difference with $* * P<0.01$ was considered statistically significant.

\section{DISCUSSION}

Chronic liver diseases are amongst the top leading causes of death in world. Advanced cirrhosis leads to a complex syndrome of chronic liver failure which involves many different organs besides the liver, including the brain, heart and systemic circulation, adrenal glands, lungs, and kidneys. The high morbidity and mortality secondary to chronic liver failure is due to complications related to the dysfunction of these organs, either alone or, more frequently, in combination ${ }^{(27)}$. Understanding the mechanisms leading to organ dysfunction is crucial to the development of strategies for treatment and prevention of complications of cirrhosis.

There is evidence that indicates that impairment in circulatory function is the main cause of renal dysfunction in cirrhosis. The dysfunction in the systemic arterial circulation is largely characterized by a reduction in systemic vascular resistance due to primary arterial vasodilation of the splanchnic circulation triggered by portal hypertension ${ }^{(24)}$. The pathophysiological mechanisms include increased renal arterial resistance, especially affecting the cortex of kidneys, which results in renal hypoperfusion, and arterial hypoten$\operatorname{sion}^{(10,13)}$. This is a situation of difficult handling and same that the liver transplant can solved the condition of renal insufficience, treatment alternatives capable to protect the renal tissue must be researched.

Oxidative stress, which is markedly elevated in chronic liver disease, has gain attention as a potential important factor in altered hemodynamics and renal dysfunction in cirrhosis.

Few studies analyze the effect of oxidative stress in the kidney as result of cirrhosis a time that there is consensus of that the renal dysfunction in the cirrhosis is a result of the hemodynamic alterations and activation of compensatory hormonal mechanisms as the increase in the activity of the system renin-angiotensin-aldosterone and simpatetic activation. However, the generation of reactive species of oxygen in peripheral organs increases the initial damage and compromises the capacity of recovery of the tissues collaborating for one worse prognostic of the cirrhosis.

In this line our objective was to identify, in a model of experimental cirrhosis, the presence of precocious oxidative damage in the kidney and its implications in the cellular integrity.

BDL is used as an animal model of secondary biliary cirrhosis and, in 4 weeks, establishes cirrhosis with progressive and fatal damages to the liver. This model simulates the human disease, generating alterations from the inflammatory reaction caused by biliary ebb and the consequent disorganization of the parenchyma architecture, inflammatory and collagen depositions, and fibrosis formation ${ }^{(12,20)}$. BDL rats develop renal dysfunction with an increase in plasma creatinine; this is associated with an increase in the plasma renin activity suggestive of underlying circulatory dysfunction as has been described in patients with advanced cirrhosis ${ }^{(25)}$. Animals at two weeks of BDL exhibited a well-preserved renal function, suggesting that the renal homeostatic compensatory mechanisms remained intact at this moment of 
hepatic damage. However, the progression of the process culminates in a non-compensated state, as already shown by rats at 4 weeks of BDL with ascites, changes in water balance, sodium retention and increased serum creatinine levels ${ }^{(21)}$.

In this study, we used animals with 4 weeks of BDL, that present well established cirrhosis and presence of functional alterations in kidneys ${ }^{(20,21)}$. Morphological alterations in kidney tissue had not been observed, what also it is in accordance with literature for this model.

In cirrhotic animals, there is a considerable increase in liver lipoperoxidation due to the formation of ROS, which has already been shown in hepatic tissue and eritrocytes by other studies ${ }^{(28,30)}$. The increased oxidative stress in the BDL model can be explained by endotoxemia and increased biliary acids, which can lead to an imbalance in the mitochondrial electron transport chain and can subsequently favor increased production of $\operatorname{ROS}^{(20,31)}$.

In this study we observed an increase in oxidative damage in the kidney of the BDL animals compared to the control rats. There were an increase in the lipoperoxidation, as well as increase in the production of ROS and reduction in the mitochondrial membrane potential (MMP) that it confirms that the increased intracellular production of ROS in this illness promotes injury mitochondrial and of cellular membranes.

On the other hand, we evaluated the activity of antioxidants enzymes in the kidney of cirrhotic animals and there were a increase in SOD, CAT and GPx activity in relation to the controls. These data seem to indicate that the defense systems are activated in an attempt to minimize the oxidative damages. Other studies in this model had shown reduction in the activity of antioxidants enzymes in liver and erythrocytes in the cirrhotic animals ${ }^{(22,31)}$. In the kidney, the antioxidant activity seems to be still preserved a time that the renal damage is subsequent to the liver damage.

Oxidative stress is not only a causative factor of cellular injury but also a pivotal regulator of all crucial cellular processes including metabolism, growth, differentiation and death directly or indirectly it is implicated in all major physiological and pathological processes ${ }^{(11)}$.

When we analyze the cellular viability, the results clearly indicated alteration on cell proliferation and there was reduction in cell survivability with viability percentage of $64.66 \%$ in BDL group. Moreover, in BDL animals there was an increase in the cells in apoptose with an increased of active caspase-3 when compared with control group and consid- erable increase in the damage to the DNA in the kidneys of the cirrhotic animals.

These results support the idea that ROS increased cause damage in the DNA and apoptose getting worse the primary renal disfunção. In support of this view, studies have shown that antioxidants may delay the development of a hyperdynamic circulatory state in experimental cirrhosis and improve renal function in patients with hepatorenal syndrome ${ }^{(1,28)}$.

Oxidative stress plays a fundamental role in the aggravation of liver injury and in the structural and/or functional derangements of diverse organs as kidney, complicating the course of advanced liver disease ${ }^{(8,28)}$.

The systematic investigation of the use of antioxidants in cirrhosis and its complications is important for development of new treatment approach for advanced liver disease.

\section{CONCLUSION}

Few studies analyze the effect of oxidative stress in the kidney as result of cirrhosis a time that there is consensus of that the renal dysfunction in the cirrhosis is a result of the hemodynamic alterations and activation of compensatory hormonal mechanisms.

In this paper we show that, although no detectable structural changes, there is loss of integrity and cellular function in the kidney, with apoptosis, caspase-3 active, oxidative damage to cell membranes and DNA caused by oxidative stress triggered by liver cirrhosis.

\section{Financial support}

Research supported by grants from the Brazilian Agencies Conselho Nacional de Desenvolvimento Científico e Tecnológico (CNPq/INCT/INPeTAm, Grant no. 573695/20083), Programa Nacional de Cooperação Acadêmica/Coordenação de Aperfeiçoamento de Pessoal de Nível Superior (CAPES) and Fundação de Amparo a Pesquisa do Estado do Rio Grande do Sul (FAPERGS - PRONEX/FAPERGS/ CNPq, Grant no. 10/0044-3).

\section{Author contribution}

Silveira KCS and Viau CM performed the research, Colares JR was responsible for the experimental model, Saffi J contributed with new reagents and analytic tools, Marroni NP and Porawski M designed the research and wrote the paper. 
Silveira KCS, Viau CM, Colares JR, Saffi J, Marroni NP, Porawski M. Cirrose induz apoptose em tecido renal através de estresse oxidativo intracelular. Arq Gastroenterol. 2015,52(1):65-71.

RESUMO - Contexto - A falência renal é uma complicação grave e frequente em pacientes com cirrose descompensada. Objetivo - Avaliar o estresse oxidativo, o dano ao DNA e alterações na função celular no rim em um modelo animal de cirrose. Métodos - A cirrose biliar secundária foi induzida em ratos através da ligadura do duto biliar comum. Foi medido no rim o TBARS (substâncias que reagem ao ácido tiobarbitúrico), ERO (espécies reativas de oxigênio), o potencial de membrana mitocondrial e a atividade das enzimas antioxidantes. A viabilidade celular foi determinada utilizando o ensaio de exclusão do trypan-blue. Para distinguir células em apoptose ou necrose foram usados os marcadores: Anexina V-PE e 7-AAD e o ensaio cometa foi utilizado para determinar dano ao DNA. Resultados - Em animais cirróticos houve um aumento significativo da lipoperoxidação no rim e na quantidade de ERO intracelular. Foi observado um aumento na atividade de todas as enzimas antioxidantes. A porcentagem de viabilidade celular foi superior a $90 \%$ no grupo controle e de $64,66 \%$ no grupo da ligadura do duto biliar. O padrão de morte celular predominante foi apoptose e houve dano ao DNA no grupo da ligadura do duto biliar. Observou-se uma redução no potencial de membrana mitocondrial no grupo da ligadura do duto biliar $(34,48 \% \pm 11,40 \%)$ em comparação aos controles $(71,40 \% \pm 6,35 \%)$. Conclusão - Esses resultados parecem indicar que nos animais cirróticos ocorre um aumento no dano oxidativo e ao DNA levando as células renais à apoptose, o que contribui para a falência renal na cirrose.

DESCRITORES - Cirrose hepática. Insuficiência renal. Estresse oxidativo. Citometria de fluxo. Espécies reativas de oxigênio.

\section{REFERENCES}

1. Assimakopoulos SF, Gogos C, Labropoulou-Karatza C. Could antioxidants be the "magic pill" for cirrhosis-related complications? A pathophysiological appraisal. Med Hypotheses. 2011;77(3):419-23.

2. Bass DA, Parce JW, Dechatelet LR, Szejda P, Seeds MC, Thomas M. Flow cytometric studies of oxidative product formation by neutrophils: a graded response to membrane stimulation. J Immunol. 1983;130(4):1910-7.

3. Burlinson B, Tice RR, Speit G, Agurell E, Brendler-Schwaab SY, Collins AR, Escobar P, et al. Fourth International Workgroup on Genotoxicity testing: results of the in vivo Comet assay workgroup. Mutat Res. 2007;627(1):31-5.

4. Cederbaum AI, Lu Y, Wu D. Role of oxidative stress in alcohol-induced liver injury. Arch Toxicol. 2009;83(6):519-48.

5. Chance B, Machley AL. Assays of catalases and peroxidases. Methods in Enzymology. 1954;2:764-75.

6. Collins AR, Ma AG, Duthie SJ. The kinetics of repair of oxidative DNA damage (strand breaks and oxidised pyrimidines) in human cells. Mut Res. 1995;336(1):69-77.

7. Devi SL, Periyaswamy V, Carani VA. Regression of liver fibrosis by taurine in rats fed alcohol: effects on collagen accumulation, selected cytokines and stellate cell activation. Eur J Pharmacol. 2010;647(1-3):161-170.

8. Dias AS, Porawski M, Alonso M, Marroni N, Collado PS, González-Gallego J. Quercetin Decreases Oxidative Stress, NF-\{kappa\} B Activation, and iNOS Overexpression in Liver of Strepptozocin-Induced Diabetic Rats. J Nutrition. 2005;135(10):2299-304

9. Flohe L, Guntzler WA. Glutathione peroxidase. Methods in Enzymol. 1974;105:115-21.

10. Guevara M, Ginès P. Hepatorenal syndrome. Dig Dis. 2005;23:47-55.

11. Halliwell B, Gutteridge CMJ. Free radicals in biology and medicine. Fourth Edition, Oxford University Press, 2007.

12. Kountouras J, Billing BH, Scheuer PJ. Prolonged bile duct obstruction: a new experimental model for cirrhosis in the rat. Br J Exp Pathol. 1984;65(3):305-11.

13. Lata J. Hepatorenal syndrome. World J Gastroenterol. 2012;18(36):4978-84

14. Lowry OH, Rosebrough NJ, Farr AL, Randall RJ. Protein measurement with the Folin phenol reagent. J Biol Chem. 1951;193(1):265-75.

15. Misra HP, Fridovich I. The role of superoxide anion in the autoxidation of epinephrine and a simple assay for superoxide dismutase. J Biol Chem. 1972;247(10):3170-5.

16. Nadin SB, Vargas-Roig LM, Ciocca DR. A silver staining method for single-cell gel assay. J Histochem Cytochem. 2001;49(9):1183-6.

17. Oberti F, Vuillemin E, Fort J, Cales P. Experimental models of portal hypertension. Gastroenterol Clin Biol. 2000;24(10):896-901.

18. Ohkawa H, Ohishi N, Yagi K. Assay for lipid peroxides in animal tissues by thiobarbituric acid reaction. Anal Biochem. 1979;95(2):351-8.
19. Parola M, Robino G. Oxidative stress-related molecules and liver fibrosis. J Hepatol. 2007;35(2):297-306.

20. Pastor A, Collado PS, Almar M, González-Gallego J. Antioxidant enzyme status in biliary obstructed rats: effects of N-acetylcysteine. J Hepatol. 1997;27(2):363-70.

21. Pereira RM, dos Santos RA, Oliveira EA, Leite VH, Dias FL, Rezende AS, Costa LP, et al. Development of hepatorenal syndrome in bile duct ligated rats. World J Gastroenterol. 2008;14(28):4505-11

22. Peres W, Tuñon MJ, Collado PS, Herrmann S, Marroni NP, González-Gallego J. The flavonoid quercetin ameliorates liver damage in rats with biliary obstruction J Hepatol 2000;33(5):742-50.

23. Poo JL, Estanes A, Pedraza-Chaverri J, Cruz C, Perez C, Huberman A, Uribe M Chronology of portal hypertensiom, decreased sodium excretion, and activation of the renin-angiotensin system in experimental biliary cirrhosis. Rev Invest Clin. 1997;49(1):15-23.

24. Schrier RW, Arroyo V, Bernardi M, Epstein M, Henriksen JH, Rodés J. Peripheral arterial vasodilation hypothesis: a proposal for the initiation of renal sodium and water retention in cirrhosis. Hepatology. 1988;8(5):1151-7.

25. Shah N, Dhar D, El Zahraa Mohammed F, Habtesion A, Davies NA, Jover-Cobos M, Macnaughtan J, et al. Prevention of acute kidney injury in a rodent model of cirrhosis following selective gut decontamination is associated with reduced renal TLR4 expression. J Hepatol. 2012;56(5):1047-53.

26. Singh NP, McCoy MT, Tice RR, Schneider EL. A simple technique for quantitation of low levels of DNA damage in individual cells. Exp Cell Res. 1988;175(1):184-91.

27. Solà E, Ginès P. Renal and circulatory dysfunction in cirrhosis: current management and future perspectives. J Hepatol. 2010;53(6):1135-45.

28. Tieppo J, Vercelino R, Dias AS, Silva Vaz MF, Silveira TR, Marroni CA, Marroni NP, et al. Evaluation of the protective effects of quercetin in the hepatopulmonary syndrome. Food Chem Toxicol. 2007;45(7)1140-6.

29. Viau CM, Guecheva TN, Sousa FG, Pungartnik C, Brendel M, Saffi J, Henriques JA. $\mathrm{SnCl}(2)$-induced DNA damage and repair inhibition of MMS-caused lesions in V79 Chinese hamster fibroblasts. Arch Toxicol. 2009;83(8):769-75.

30. Viau CM, Moura DJ, Facundo VA, Saffi J. The natural triterpene $3 \beta, 6 \beta, 16 \beta-$ trihydroxy-lup-20(29)-ene obtained from the flowers of Combretum leprosum induces apoptosis in MCF-7 breast cancer cells. BMC Complement Altern Med. 2014; $14: 280$.

31. Vieira EK, Bona S, Di Naso FC, Porawski M, Tieppo J, Marroni NP. Quercetin treatment ameliorates systemic oxidative stress in cirrhotic rats. ISRN Gastroenterol. 2011;2011:604071.

32. Yura T, Fukunaga M, Khan R, Nassar GN, Badr KF, Montero A. Free-radical-generated F2-isoprostane stimulates cell proliferation and endothelin-1 expression on endothelial cells. Kidney Int. 1999;56(2):471-8.

Received 26/5/2014 Accepted 7/10/2014 